\title{
The Effect of Benefits Gained from Leisure Activities on Entrepreneurship and Academic Hopelessness
}

\author{
Anıl Siyahtaş (Corresponding author) \\ Faculty of Sports Sciences \\ Istanbul University-Cerrahpaşa, Istanbul, Turkey \\ E-mail: anil.siyahtas@hotmail.com \\ Veli Ozan Çakır \\ Faculty of Sports Sciences \\ Alanya Alaaddin Keykubat University, Antalya, Turkey \\ E-mail: veliozancakir@gmail.com
}

Received: July 10, 2021 Accepted: August 13, 2021 Published: August 26, 2021

doi:10.5296/jei.v7i2.18848 URL: https://doi.org/10.5296/jei.v7i2.18848

\begin{abstract}
The importance of the benefits that individuals get from the activities they participate in their leisure is increasing day by day. It is known that the benefits gained are reflected positively in many aspects of the individual's life. From this point of view, this study aimed to examine the effect of the benefits obtained by university students in their leisure on the prediction of entrepreneurship and academic hopelessness. The study group of the research consisted of a total of 457 students, 247 males and 210 females, selected by easy sampling method, and studying at Istanbul University-Cerrahpaşa Faculty of Sports Sciences. In addition to the personal information form, Leisure Benefit Scale (LBS) developed by Ho (2008) and adapted into Turkish by Akgül et al. (2018); Entrepreneurship Scale (ES) developed by Yilmaz and Sünbül (2009) and Academic Hopelessness Scale (AHS) developed by Gökalp and Soykan (2020) were used as data collection tools. The normality distribution of the data was decided according to the skewness and kurtosis values. After the data showed normal distribution, t-test, Pearson Correlation test, Multiple Regression analysis were performed in the analysis. As a result, while there were differences between university students' leisure benefits and academic hopelessness according to their gender, a significant relationship was found between leisure benefits and entrepreneurship and academic hopelessness. In this context, it
\end{abstract}


was concluded that social benefit from leisure benefits was a significant predictor of entrepreneurship and academic hopelessness.

Keywords: Leisure, Leisure benefit, Entrepreneurship, Academic hopelessness

\section{Introduction}

In the 21st century, leisure has emerged as an important condition in people's lives. Increasing economic well-being of individuals, improved health status, increased education level, reduced working hours and a greater sense of freedom make leisure more important for people (Hsieh, Spaulding \& Riney, 2004). Because leisure give people a chance to improve their living conditions, it is seen as a driving force of great importance for their health, peace and happiness (Çetin, 2019). While Chen et al. (2013) drawing attention to the importance of leisure, stating that leisure plays a key role in people's enjoyment and success; Edginton (2006) has also emphasized the importance of leisure by expressing that it is an important element that contributes to the social, cultural and economic welfare of societies and nations rather than people.

While evaluating the leisure of individuals negatively can cause various problems, as well as evaluating the leisure positively brings various benefits for the individual and society (Güçlü, 2013). In particular, the benefit gained in leisure activities is of great importance in increasing the quality of life as well as making the lives of individuals valuable and meaningful (Iwasaki, 2006). Tezcan (1994) has stated that making useful consumption of leisure with positive activities is an important condition of developing a healthy personality, and individuals satisfy their entertainment and rest needs with leisure activities and as a result, they live a happy life. Individuals aim to benefit by participating in various activities in their leisure. When the literature is examined, studies make various classifications considering the different benefits of leisure activities on individuals. Bammel and Burrus (1996) identified the benefits of leisure in six dimensions as physiological, psychological, relaxation, educational, aesthetic and social; Tekin et al. (2017) physical, mental and emotional health, knowledge and character development, social cohesion, aesthetics, spirituality and adventure; Ho (2008), on the other hand, classified the benefits in nine dimensions as physiological, psychological, social, educational, economic, environmental, relaxation, aesthetic and emotional. On the other hand, Hung (2012) classified the benefits of leisure according to three basic groups as physical, psychological and social benefits. While individuals participate in leisure activities, they gain physiological benefits such as improving their body health, keeping diseases under control, and maintaining body weight at the desired level (Bright, 2000); According to Munusturlar (2016), individuals also gain psychological benefits such as mental health, personal development and personal value and satisfaction in their leisure. In addition to gaining physical and psychological benefits in leisure activities, individuals also gain social benefits by strengthening family ties, developing social relations and skills, experiencing new interpersonal relationships and cultural experiences (Serdar, 2020).

Entrepreneurship has historically been one of the oldest activities (Landström, 2005). It is an important factor in the improvement, development and progress of countries. From the past, it 
is showing as an indispensable factor that ensures the financial, social and cultural development of people, regions and societies (Damar, 2015). For this reason, the concept of entrepreneurship has an important place in study fields today (Yüceol, 2018). Bozkurt et al. (2012) states that entrepreneurship has two functions as economic and social. Entrepreneurship in economic fields has an important function in the growth of the economy and the emergence of new industries (Carree \& Thurik, 2003), increasing the level of welfare (İlhan, 2005) and preventing unemployment (Bozkurt et al., 2012). In the social areas of entrepreneurship; it plays an active role in creating value, at the beginning of an innovative process and the change and development of all societies (Bozkurt et al., 2012). Today, where entrepreneurship gains great importance, it is extremely important to identify entrepreneurial individuals as characters and to properly train and guide these individuals by institutions such as universities whose main task is to educate (Demir et al., 2015). Entrepreneurship education in universities is very important because it helps individuals to know the rules of behaviour that should be for a quality entrepreneur together with the education they receive at universities (Linan et al., 2008; cited from Karıman, 2017). At this point, universities have a great responsibility. The number of individuals graduating from universities in Turkey is increasing every year, and the number of students is also increasing (Ertekin, 2020). Therefore, individuals studying at the university should guide and support the importance and awareness of entrepreneurship in such an important issue for the future of the country (Demir et al., 2015).

The most important of the education stages of people is considered to be university. Because university education plays an important role in shaping and directing the future lives of individuals (Rençber, 2012). Individuals can take many responsibilities during this university education, but one of the most important dimensions in the process of obtaining a profession, which is thought to shape their future, is the academic dimension (Çelikkaleli \& Akbay, 2013). Academic success is inevitable during the education life of university students because academic success plays an important role in the education process. The most important reason for this is that in guiding the individual in the future, their academic achievements also be taken into account when they enter business life (Karaman, 2018). While the academic situation is such importance for university students, the academic responsibilities of the students and the negativities in their success can also lead to consequences that will lead the students to drop out of education (Zajacova et al., 2005). Therefore, it can be said that many variables affect academic achievement (Polat, 2017). These variables affect students' hopes as well as their success. Students' hope levels are shaped according to their expectations and plans. Academic hopelessness may occur when these expectations are not met (Gökalp \& Soykan, 2020). Today, with the advancement of technology and mechanization, individuals have more leisure compared to the past. There have been many studies (Avunduk, 2021a, 2021b; Ayyıldız Durhan \& Karaküçük, 2017; Beşikçi et al., 2019; Bülbül et al., 2021; Chen et al., 2013; Chin-Tsai, 2013; Çakır, 2017; Dergance et al., 2003; Erdemli \& Yaşartürk, 2020; Erdemli, 2019; Ertüzün et al., 2020; Gökçe, 2015; Güldür \& Yaşartürk, 2020; Heintzman, 2009; Huang et al., 2014; Huang, 2013; Karaküçük et al., 2019; Kocaer, 2018; Lee et al., 2015; Philipp, 1997; Serdar, 2020; Serdar \& Demirel, 2020; Serdar et al., 2018; Shyu, 2012; Siyahtaş, 2020; Şeras, 2017; Üstün \& Aktaş Üstün, 2020; Yan, 2013) have examined the 


\section{Macrothink}

benefits of leisure activities in which individuals use their leisure participating.

When the literature is examined, it can found that many studies (Arslan, 2002; Aydın \& Öner, 2016; Bilge \& Bal, 2012; Chen \& Lai, 2010; Çelik et al., 2014; H. Çolakoğlu \& T. Çolakoğlu, 2016; Doğaner \& Altunoğlu, 2010; Ertekin, 2021; Keleş et al., 2015; Koh, 1996; Korkmaz, 2012; Pan \& Akay, 2015; Pihie \& Akmaliah, 2009; Shariff \& Saud, 2009; Şeşen \& Basım, 2012; Tays1 \& Canbaz, 2014; Thandi \& Sharma, 2003; Yüksel et al., 2015) have been conducted to determine the entrepreneurship levels of university students. Studies about academic achievement (Y1ldız et al., 2021), academic procrastination (Filiz \& Doğan, 2021), academic motivation (Demir \& Arı, 2013), academic self-efficacy (Seki Öz et al., 2021) and academic self-perception (İşmar \& Şehitoğlu, 2021) have also been found in studies to determine their academic status in the literature. However, no study has been found that determines the academic hopelessness of individuals studying at university.

The studies showing the benefit obtained from leisure activities of individuals affects every aspect of life and a change is experiencing. In this context, this study aimed to determine the relationship between the benefit of the university students who have the most leisure today and their entrepreneurship and academic hopelessness and determine the differences between leisure utility, entrepreneurship and academic hopelessness according to various variables. Within the scope of this study, answers to the following questions were sought in the main purpose of the study;

- Does the benefit obtained by university students in their leisure predict their entrepreneurship?

- Does the benefit obtained by university students in their leisure predict their academic hopelessness?

\section{Method}

\subsection{Research Model}

This research performed by the screening model, one of the quantitative research methods. In the scanning pattern, it allowed defining the tendencies, attitudes or views of the universe quantitatively or numerically by working with a sample in this universe (Creswell, 2017).

\subsection{Research Group}

The study group of the research consisted of a total of 457 students, 247 male (54\%) and 210 female (46\%) selected by easy sampling method, studying at Istanbul University-Cerrahpaşa Faculty of Sports Sciences. The descriptive statistics of the personal characteristics of the research group were shown in Table 1. 
Table 1. Descriptive statistics of participants' personal characteristics

\begin{tabular}{|l|l|l|l|}
\hline & & $\mathbf{f}$ & $\mathbf{\%}$ \\
\hline \multirow{5}{*}{ Gender } & Male & 247 & 54.0 \\
\cline { 2 - 4 } & Female & 210 & 46.0 \\
\cline { 2 - 4 } & Total & 457 & 100.0 \\
\hline \multirow{5}{*}{ Age Group } & $18-21$ & 125 & 27.4 \\
\cline { 2 - 4 } & $22-25$ & 109 & 23.9 \\
\cline { 2 - 5 } & $26-29$ & 102 & 22.3 \\
\cline { 2 - 4 } & 30 years old and older & 121 & 26.5 \\
\cline { 2 - 4 } & Total & 457 & 100.0 \\
\hline & Low & 238 & 52.1 \\
\cline { 2 - 4 } & Medium & 112 & 24.5 \\
\cline { 2 - 4 } & High & 107 & 23.4 \\
\cline { 2 - 4 } & Total & 457 & 100.0 \\
\hline
\end{tabular}

In Table 1, there were descriptive statistics that include the personal characteristics of the individuals participating in the research. According to the table, a total of 457 students, 247 male $(54 \%)$ and 210 female (46\%), participated in the study. It was determined that 125 (27.4\%) of the individuals participating in the research were in the "18-21 age group"; 109 $(23.9 \%)$ were in the "22-25 age group" and 102 (22.3\%) were in the "26-29 age group" and $121(26.5 \%)$ were "30 years old and older". It was determined that While 238 students $(52.1 \%)$ in the research group saw the perception of welfare level as "low"; 112 (24.5\%) were "medium" and 107 (23.4\%) expressed a "high" opinion.

\subsection{Data Collection Tools}

In the research, the "Recreation Benefit Scale", "Entrepreneurship Scale" and "Academic Hopelessness Scale" were used as well as the "personal information form" created by the researcher, which included the gender, age group and perceived welfare level of university students.

\subsubsection{Leisure Benefit Scale (LBS)}

The Leisure Benefit Scale was developed by Ho (2008) and adapted to Turkish by Akgül et al. (2018) for validity and reliability study. RBS consisted of a 5-point Likert type (1-strongly disagree, 5-strongly agree) and consisted of 24 items. LBS consisted of three sub-dimensions: physical, psychological and social. The Cronbach Alpha internal consistency coefficient for the overall scale was .83 , and the internal consistency coefficients calculated for the three 
sub-dimensions range from .80 to .86 .

\subsubsection{Entrepreneurship Scale (ES)}

The Entrepreneurship Scale was developed by Y1lmaz and Sünbül (2009) to measure the entrepreneurship levels of university students. ES was a 5-point Likert type (1-never, 5-very often), and consisted of 36 items and a single factor. The scores obtained from the sum of the articles and the entrepreneurship levels of university students were evaluated according to the table below (Table 2).

Table 2. Entrepreneurship levels

\begin{tabular}{|l|l|}
\hline $36-34$ & Very Low Entrepreneurship \\
\hline $65-92$ & Low Entrepreneurship \\
\hline $93-123$ & Medium Entrepreneurship \\
\hline $124-151$ & High Entrepreneurship \\
\hline $152-180$ & Very high Entrepreneurship \\
\hline
\end{tabular}

\subsubsection{Academic Hopelessness Scale (AHS)}

The Academic Hopelessness Scale was developed by Gökalp and Soykan (2020) to determine the academic hopelessness levels of students. AHS consists of a 4-point Likert type (1-never, 4-always). AHS consists of 16 articles and 3 sub-dimensions. Sub dimensions; behavioural (7 articles), cognitive (4 articles) and environmental (5 articles). The Cronbach Alpha coefficient for the overall scale was calculated as .83. The Cronbach Alpha internal consistency coefficients for the sub-dimensions of the scale (behavioural, cognitive, environmental) were found as .78, .74 and .63, respectively. The highest score that can be obtained in the "behavioural" sub-dimension of AHS was 28, the lowest score was 7. The highest possible score in the "cognitive" sub-dimension was 16 , and the lowest was 4 . In the "environmental" sub-dimension, the highest score that can be obtained was 20 , and the lowest score was 5 . The highest score that can be obtained for the overall scale was 64, and the lowest score was 16. For students, the higher the score from the scale, the higher the level of academic hopelessness.

\subsection{Analysis of Data}

Analysis of the research data performed by using the SPSS 20 package program. Frequency (f) and percentage (\%) methods were used for the descriptive statistics of the research group's personal information. Firstly, internal consistency coefficients were calculated for the totals and sub-dimensions of the scales in the analysis of the data. The Cronbach Alpha coefficients calculated about the totals and sub-dimensions of the scales were given in Table 3. To understand whether the research data showed a normal distribution, skewness and kurtosis 
values were examined. As can be seen in Table 4, it can be seen that the skewness and kurtosis values of the scales used in the research were between \pm 2 . According to George and Mallery (2010), the data being between \pm 2 stated that the data was sufficient for a normal distribution. Therefore, it was accepted that the data for this study were normally distributed. After the data show normal distribution, t-Test to determine the differences between the variables; Pearson Correlation test to detect the relationship between variables; Two separate Multiple Regression analyzes were used to examine the effect of independent variables on the dependent variable.

Table 3. Calculated Cronbach's Alpha coefficients of scales and their sub-dimensions

\begin{tabular}{|l|l|l|l|}
\hline Scales & Sub-dimensions & Item Number & Cronbach's Alpha \\
\hline Leisure Benefit Scale & & 24 & .88 \\
\hline & Physical Benefit & 7 & .79 \\
\hline & Psychological Benefit & 8 & .81 \\
\hline Entrepreneurship Scale & Social Benefit & 9 & .84 \\
\hline Academic Hopelessness Scale & & 36 & .87 \\
\hline & Behavioural & 7 & .79 \\
\hline & Cognitive & 4 & .75 \\
\hline & Environmental & 5 & .81 \\
\hline
\end{tabular}

Table 3 showed the Cronbach Alpha internal consistency coefficients of the scales and sub-dimensions. According to the calculated Cronbach's Alpha, internal consistency coefficients; The Cronbach's Alpha internal consistency coefficient for the overall LBS was calculated as .88 , while the internal consistency coefficients for the sub-dimensions of physical benefit, psychological benefit and social benefit were calculated as $.79, .81$ and .84, respectively. The Cronbach's Alpha internal consistency coefficient calculated for the Entrepreneurship Scale, in general, was calculated as .87. The Cronbach's Alpha internal consistency coefficient calculated for the overall AHS was calculated as .79. The coefficients calculated for the behavioural, cognitive and environmental sub-dimensions were calculated as $.75, .81$ and .72 , respectively. 
Table 4. Distribution of scale scores

\begin{tabular}{|l|l|l|l|l|l|l|}
\hline & Scale Sub-Dimensions & Item Number & $\mathbf{n}$ & Mean & Skewness & Kurtosis \\
\hline \multirow{4}{*}{ LBS } & Physical Benefit & 7 & 457 & $3.58 \pm 0.74$ & -.749 & .695 \\
\cline { 2 - 7 } & Psychological Benefit & 8 & 457 & $3.57 \pm 0.81$ & -.743 & .636 \\
\cline { 2 - 7 } & Social Benefit & 9 & 457 & $3.57 \pm 0.73$ & -.822 & 1.435 \\
\hline \multirow{2}{*}{ ES } & Entrepreneurship & 36 & 457 & $98.59 \pm 18.24$ & -.142 & .169 \\
\hline \multirow{3}{*}{ AHS } & Behavioral & 7 & 457 & $23.96 \pm 2.64$ & .110 & -1.379 \\
\cline { 2 - 7 } & Cognitive & 4 & 457 & $13.52 \pm 2.04$ & -.482 & -.633 \\
\cline { 2 - 7 } & Environmental & 5 & 457 & $16.33 \pm 2.66$ & -.169 & -.798 \\
\hline
\end{tabular}

Table 4 showed the scale scores obtained from the individuals participating in the research. When the table was examined, it was determined that the highest mean in the sub-dimensions of LBS was in the "physical benefit" sub-dimension (3.58 \pm 0.74$)$. It was determined that the mean obtained from the entrepreneurship scale was $98.59 \pm 18.24$. In the AHS sub-dimensions, it was determined that the highest mean was in the "behavioural" sub-dimension (23.96 \pm 2.64$)$, and the lowest mean was in the "cognitive" sub-dimension (13.52 \pm 2.04$)$.

\section{Results}

3.1 The Effect of Gender of University Students on Leisure Benefits, Entrepreneurship, and Academic Hopelessness

Table 5 showed the results of the t-Test conducted to determine whether there was a significant difference between university students' leisure benefit, entrepreneurship and academic hopelessness according to their gender. When the table was examined, it was seen that the mean scores of female students $(\overline{\mathrm{x}}=3.66)$ in the "physical benefit" sub-dimension of LBS were higher than male students $(\overline{\mathrm{x}}=3.50)$. As a result of the analysis, the means in favour of female students were found to be statistically significant $\left(t_{(455)}=-2.116 ; p<0.05\right)$. In the "psychological benefit" sub-dimension, it was seen that the mean scores of female students $(\bar{x}=3.65)$ were higher than male students $(x=3.50)$. In the analysis, it was found that this difference between the means was not statistically significant $\left(\mathrm{t}_{(455)}=-1.883 ; \mathrm{p}>\right.$ 0.05). In the "social benefit" sub-dimension, as in other sub-dimensions, the mean scores of female students $(\overline{\mathrm{x}}=3.68)$ were higher than male students $(\overline{\mathrm{x}}=3.54)$. This difference was found statistically significant $\left(\mathrm{t}_{(455)}=-2.291 ; \mathrm{p}<0.05\right)$. 
Table 5. t-Test results of the mean levels of leisure benefits, entrepreneurship and academic hopelessness of the students by gender

\begin{tabular}{|c|c|c|c|c|c|c|c|}
\hline & & $\mathbf{n}$ & $\overline{\mathbf{x}}$ & Ss & Sd & $\mathbf{t}$ & $\mathbf{p}$ \\
\hline \multicolumn{8}{|l|}{ LBS } \\
\hline \multirow{2}{*}{ Physical Benefit } & Male & 247 & 3.50 & 0.83 & \multirow{2}{*}{455} & \multirow{2}{*}{-2.116} & \multirow{2}{*}{$.035 *$} \\
\hline & Female & 210 & 3.66 & 0.73 & & & \\
\hline \multirow{2}{*}{ Psychological Benefit } & Male & 247 & 3.50 & 0.85 & \multirow{2}{*}{455} & \multirow{2}{*}{-1.883} & \multirow{2}{*}{.060} \\
\hline & Female & 210 & 3.65 & 0.76 & & & \\
\hline \multirow{2}{*}{ Social Benefit } & Male & 247 & 3.54 & 0.76 & \multirow{2}{*}{455} & \multirow{2}{*}{-2.291} & \multirow{2}{*}{$.022 *$} \\
\hline & Female & 210 & 3.68 & 0.69 & & & \\
\hline \multicolumn{8}{|l|}{ ES } \\
\hline \multirow{2}{*}{ Entrepreneurship } & Male & 247 & 98.27 & 18.49 & \multirow{2}{*}{455} & \multirow{2}{*}{-.411} & \multirow{2}{*}{.681} \\
\hline & Female & 210 & 96.31 & 16.97 & & & \\
\hline \multicolumn{8}{|l|}{ AHS } \\
\hline \multirow{2}{*}{ Behavioural } & Male & 247 & 24.13 & 2.62 & \multirow{2}{*}{455} & \multirow{2}{*}{1.533} & \multirow{2}{*}{.126} \\
\hline & Female & 210 & 23.75 & 2.66 & & & \\
\hline \multirow{2}{*}{ Cognitive } & Male & 247 & 11.28 & 2.08 & \multirow{2}{*}{455} & \multirow{2}{*}{-2.780} & \multirow{2}{*}{$.006 *$} \\
\hline & Female & 210 & 13.81 & 1.97 & & & \\
\hline \multirow{2}{*}{ Environmental } & Male & 247 & 16.10 & 2.60 & \multirow{2}{*}{455} & \multirow{2}{*}{-2.035} & \multirow{2}{*}{$.022 *$} \\
\hline & Female & 210 & 13.41 & 2.71 & & & \\
\hline
\end{tabular}

This difference was found statistically significant. According to the entrepreneurship scale, it was seen that the mean scores of male students $(\bar{x}=98.27)$ were higher than female students $(\bar{x}=96.31)$. As a result of the analysis, this result which was in favour of male students was not found statistically significant $\left(\mathrm{t}_{(455)}=-.411 ; \mathrm{p}>0.05\right)$.

When the students' academic hopelessness levels were examined, it was seen that the mean scores of female students $(\overline{\mathrm{x}}=23.75)$ in the "behavioural" sub-dimension were lower than male students $(\overline{\mathrm{x}}=24.13)$. As a result of the analysis, this result in favour of females was not found statistically significant $\left(\mathrm{t}_{(455)}=1.533 ; \mathrm{p}>0.05\right)$. In the "cognitive" sub-dimension, it was seen that the mean scores of male students $(\overline{\mathrm{x}}=11.28)$ were lower than female students $(\bar{x}=13.81)$. This result in favour of male students was found statistically significant $\left(\mathrm{t}_{(455)}=\right.$ -2.780; $\mathrm{p}<0.05)$. Finally, in the "environmental" sub-dimension, it was seen that mean scores of female students $(\overline{\mathrm{x}}=13.41)$ were lower than male students $(\overline{\mathrm{x}}=16.10)$. This result, which was in favour of female students, was statistically significant $\left(\mathrm{t}_{(455)}=-2.035 ; \mathrm{p}<0.05\right)$. 
3.2 The Relationship between Leisure Benefits and Entrepreneurship and Academic Hopelessness

Table 6. Correlation Results between Leisure Benefits and Entrepreneurship and Academic Hopelessness Sub-Dimensions

\begin{tabular}{|c|c|c|c|c|c|}
\hline & & & Physical Benefit & Psychological Benefit & Social Benefit \\
\hline \multirow{2}{*}{ ES } & \multirow{2}{*}{ Entrepreneurship } & $\mathrm{r}$ & .122 & .045 & .318 \\
\hline & & $\mathrm{p}$ & .641 & .339 & $.000 *$ \\
\hline \multirow{6}{*}{ AHS } & \multirow{2}{*}{ Behavioral } & $\mathrm{r}$ & -.265 & -.368 & .285 \\
\hline & & $\mathrm{p}$ & .743 & .841 & .926 \\
\hline & \multirow{2}{*}{ Cognitive } & $\mathrm{r}$ & -.179 & -.171 & -.050 \\
\hline & & $\mathrm{p}$ & .664 & $.000 *$ & .284 \\
\hline & \multirow{2}{*}{ Environmental } & $\mathrm{r}$ & -.236 & -.442 & -.224 \\
\hline & & $\mathrm{p}$ & .551 & .874 & $.000 *$ \\
\hline
\end{tabular}

Table 6 showed the results of the Pearson Correlation test to determine whether there was a statistically significant relationship between the leisure benefits and entrepreneurship and academic hopelessness.

According to the analysis results, a statistically significant relationship did not found between physical benefit and entrepreneurship $(\mathrm{p}>0.05)$. Similarly, a statistically significant relationship did not found between psychological benefit and entrepreneurship $(\mathrm{p}>0.05)$. A statistically significant relationship did found between social benefit and entrepreneurship. The detected relationship was moderately positive $(\mathrm{p}<0.05 ; \mathrm{r}=.31)$.

In the analysis, a statistically significant relationship did not found between the "behavioural", "cognitive" and "environmental" which were sub-dimensions of the AHS and physical benefit $(\mathrm{p}>0.05)$. While a statistically significant relationship did not found between psychological benefit and "behavioural" and "environmental" sub-dimensions ( $p>0.05)$; a significant relationship did found between the "cognitive" sub-dimension. The detected relationship was a low-level negative relationship $(p<0.05 ; r=-.17)$. While a statistically significant relationship did not found between social benefit and "behavioural" and "cognitive" sub-dimensions ( $p>0.05$ ); a statistically significant relationship did found between the "environmental" sub-dimension. The significant relationship found was a low-level negative relationship $(\mathrm{p}<0.05 ; \mathrm{r}=-.22)$. 


\subsection{The Predicting Effect of Leisure Benefits on Entrepreneurship}

Table 7. The Effect of Leisure Benefits on Predicting Entrepreneurship Multiple Regression Results

\begin{tabular}{|l|l|l|l|l|l|}
\hline Model & $\mathbf{B}$ & Standard Error & $\boldsymbol{\beta}$ & $\mathbf{t}$ & $\mathbf{p}$ \\
\hline (Constant) & 13.252 & .749 & & 22.167 & .000 \\
\hline Physical Benefit & .215 & .423 & .041 & .655 & .512 \\
\hline Psychological Benefit & .362 & .467 & .088 & .861 & .326 \\
\hline Social Benefit & .723 & .241 & .157 & 6.475 & $\mathbf{. 0 0 0}^{*}$ \\
\hline $\mathrm{R}^{2}=.251 ;$ adj. $\mathrm{R}^{2}=.175$ & $\mathrm{l}$ & \\
\hline $\mathrm{F}=65.122 ; \mathrm{p}<0.05$ &
\end{tabular}

Table 7 showed the results of the Multiple Regression analysis conducted to examine the predictive effect of leisure benefits on entrepreneurship. This model was found statistically significant according to the result of the analysis $(\mathrm{F}=65.122 ; \mathrm{p}<0.05)$. In the analysis, it was found that leisure benefits explained entrepreneurship in students by approximately $17 \%$ $\left(\operatorname{adj} . \mathrm{R}^{2}=.319\right)$. When leisure benefits were examined, it was found that social benefit was a positive predictor of entrepreneurship $\left(\mathrm{R}^{2}=.251 ; \mathrm{t}=6.475 ; \mathrm{p}<0.05\right)$. In other words; It was concluded that a one-unit increase in the social benefit of leisure causes an increase of 0.723 in the level of entrepreneurship. On the other hand, the sub-dimensions of "physical benefit" $(\mathrm{t}=.655 ; \mathrm{p}>0.05)$ and "psychological benefit" $(\mathrm{t}=.861 ; \mathrm{p}>0.05)$ of leisure did not have a significant effect on the model. 
3.4 The Effect of Leisure Benefits on Predicting Academic Hopelessness

Table 8. The Effect of Leisure Benefits on Predicting Academic Hopelessness Multiple Regression Results

\begin{tabular}{|c|c|c|c|c|c|}
\hline Model & B & Standard Error & $\boldsymbol{\beta}$ & $\mathbf{t}$ & $\mathbf{p}$ \\
\hline (Constant) & 5.352 & .851 & & 17.251 & .000 \\
\hline Physical Benefit & -.214 & .561 & .091 & .287 & .941 \\
\hline Psychological Benefit & -.132 & .638 & .112 & .214 & .857 \\
\hline Social Benefit & -.225 & .267 & .126 & 5.257 & $.000 *$ \\
\hline \multicolumn{6}{|l|}{$\mathrm{R}^{2}=.214 ;$ adj. $\mathrm{R}^{2}=.107$} \\
\hline \multicolumn{6}{|l|}{$\mathrm{F}=25.183 ; \mathrm{p}<0.05$} \\
\hline
\end{tabular}

The results of the Multiple Regression analysis conducted to examine the predictive effect of the benefits obtained in leisure on academic hopelessness were given in Table 8. It was found that the regression model established according to the analysis result was significant $(\mathrm{F}=$ 25.183; $\mathrm{p}<0.05)$. According to the table; it was found that leisure benefits explained academic hopelessness in students by $10 \%\left(\operatorname{adj} . \mathrm{R}^{2}=.107\right)$. When Considering the leisure benefits, it was found that the social benefit sub-dimension was a negative and significant predictor of academic hopelessness $\left(\mathrm{R}^{2}=.214 ; \mathrm{t}=5.257 ; \mathrm{p}<0.05\right)$. In other words; It was concluded that a one-unit increase in the social benefit of leisure would cause a .225 decrease in students' academic hopelessness. In addition, it was observed that leisure did not have a significant effect on physical benefit $(\mathrm{t}=.287 ; \mathrm{p}>0.05)$ and psychological benefit $(\mathrm{t}=.214$; $\mathrm{p}>0.05)$ on academic hopelessness.

\section{Discussion}

As a result of the study analysis, it was seen that the leisure benefits of the individuals studying at the university were high. In other words, it can be said that individuals who study at the university benefit more physically in their leisure. When the literature was examined, it was found that there were differences in the benefits obtained by the individuals in the studies. For example; in the study conducted by Emrah (2021), individuals provided the highest physical benefit, while in the studies conducted by Chen and Cheng (2013) and Ayyıldız Durhan and Karakut (2017), individuals experienced psychological benefit more than the other benefit. On the other hand, in a study conducted by Karaküçük et al. (2019) and Ertüzün et al. (2020) individuals experienced more social benefits. Therefore, it can be said that today there may be changes in the benefits that individuals get in their leisure, but they benefit in any way in their leisure. 
In the results, it was seen that the entrepreneurship scores of the individuals studying at the university were 98.59. As seen in Table 2, university students can be considered as medium-level entrepreneurs since this mean was between 93-123. In the studies conducted in the literature, the entrepreneurship levels of individuals were found to be high in the studies conducted by Özmen (2015), Pan and Akay (2015), Y1lmaz and Sünbül (2009), Ertekin (2020), and Koh (1996). Therefore, the results of this study did not show parallelism with the other conducted studies.

When the means of the students in the sub-dimensions of the academic hopelessness scale were examined, the mean in the "behavioural" sub-dimension was $23.96 ; 13.52$ in the "cognitive" sub-dimension; In the "environmental" sub-dimension, it was found to be 16.33 . It can be said that the academic hopelessness of university students was high because the mean scores in the sub-dimensions were close to the limits stated by Gökalp and Soykan (2020).

As a result of the analyses performed to determine whether there was an effect of gender on leisure benefits a significant difference determined between leisure "physical benefit" and "social benefit" according to gender but a significant difference was not found between "psychological benefit". When Looking at the means, it was determined that the sub-dimensions were in favour of female students. As a result of this study, it can be said that female students gain more leisure benefits. However, in previous studies, different results were seen in the benefits obtained by gender. For example; while a statistically significant difference was found between the genders in the study conducted by Chen and Cheng; Karakucuk et al. (2019), Üstün and Aktaş Üstün (2020), Kocaer (2018) did not detect statistically significant differences. In addition, there were differences between the genders in the studies. In this study, it was seen that female individuals experienced more leisure benefits than male individuals. It has been seen that male individuals gain more leisure benefits than female individuals in some studies (Chen \& Cheng, 2013; Bülbül et al., 2021; Karakucuk et al. 2019; Serdar, 2020). Therefore, as the benefit obtained between individuals changes, the benefit obtained according to the genders also changes and it is expected that different results would be obtained depending on the time of the studies, study groups, and the way individuals use their leisure. Even though the mean scores of male students in entrepreneurship scores were higher than female students scores, the mean scores were not found statistically significant. Similar results have been reached in studies (Adatepe, 2018; Bilge \& Bal, 2012; Ertekin, 2020; Karataş, 2018; Özman, 2013; Öztürk, 2018; Pan \& Akay, 2015; Tays1 \& Canbaz, 2014; Y1ldız, 2020), no statistically significant differences were found between male and female individuals. Therefore, the results of this study showed parallelism with the studies conducted.

When the academic hopelessness states by gender were examined; While there was no significant difference was found according to gender in the "behavioural" sub-dimension; It was determined that gender had a significant effect on the "cognitive" and "environmental" sub-dimensions. While considering the mean scores of the sub-dimensions the means scores of female students were higher than male students in the "cognitive" sub-dimension. With these results, it can be said that female students experience higher academic hopelessness in 
the cognitive dimension than male students. On the other hand, a statistically significant difference was determined in the "environmental" sub-dimension; It was determined that the mean scores of male students were higher than the mean scores of female students. In other words, it can be said with these results that male students' academic hopelessness in the "environmental" sub-dimension was higher than female students.

When the relationship between university students' leisure benefits and their entrepreneurship was examined; While there was no statistically significant relationship between "physical" and "psychological" benefits from leisure benefits; A moderately positive relationship was determined between the "social" benefit and it. Considering the predictive effect of leisure benefits on entrepreneurship; It was determined that leisure benefits explain entrepreneurship by $17 \%$ in university students. In the established multiple regression model, it was determined that only social benefit among leisure benefits was a positive predictor of entrepreneurship. In other words, it can be interpreted that the social benefit that university students would gain in their leisure would also increase their entrepreneurship. When the relationship between students' leisure benefits and their academic hopelessness was examined; A low negative correlation was found between the "social benefit", one of the leisure benefits, and academic hopelessness. This can be interpreted as university students' academic hopelessness would decrease as their social benefits increase. When the effect of leisure benefits on predicting academic hopelessness state was examined; it was concluded that leisure benefits explained $10 \%$ of academic hopelessness and only social benefit was a significant predictor of academic hopelessness.

\section{Conclusion and Recommendations}

As a result of the study, it was concluded that university students get the highest benefit as a physical benefit in their leisure and they were moderate entrepreneurs. It was concluded that the academic hopelessness of university students was high and they experience the highest hopelessness behaviorally. Another result of the study was that the gender of university students affects their leisure benefits and academic hopelessness, but not on their entrepreneurship.

This study mainly aimed to examine the predictive effect of leisure benefits on entrepreneurship and academic hopelessness. As a result of the study; it was concluded that the social benefit that university students got in their leisure is a significant predictor of both entrepreneurship and academic hopelessness. Considering the relationship between them, it can be said that as the social benefits of individuals increase, their entrepreneurial characteristics can also increase, and it was found that as social benefits increase, their academic hopelessness can decrease.

These results reveals the importance of obtaining social benefits, especially in the leisure of university students. Therefore, it is recommended that university students gain benefits in their leisure, especially social benefits. University administrations are also recommended to help students make useful use of their leisure to reduce their academic hopelessness and increase their entrepreneurial characteristics. 


\section{References}

Adatepe, S. (2018). Examining entrepreneurship characteristics and reflective thinking levels of pre-service teachers at physical education and sports school (Master's Thesis, Bartin University Institute of Educational Sciences).

Akgül, B., Ertüzün, E., \& Karaküçük, S. (2018). Leisure Benefit Scale: A Study of Validity and Reliability. Gazi Journal of Physical Education and Sport Sciences, 23(1), 25-34.

Arslan, K. (2002). The tendencies of professional preferences and entrepreneurship among undergraduate students. Doğuş University Journal, 3(2), 1-11.

Avunduk, Y. (2021a). The relationship between leisure satisfaction and hopelessness. International Journal of Applied Exercise Physiology, 10(1), 1-6.

Avunduk, Y. (2021b). The relationship between leisure satisfaction and social media addictions of individuals at university. Journal of Educational Issues, 7(1), 507-522. https://doi.org/10.5296/jei.v7i1.18592

Aydın, E., \& Öner, G. (2016). Investigation of Entrepreneurship Levels of Social Studies and Classroom Teacher Candidates. Ahi Evran Üniversitesi Kırşehir Eğitim Fakültesi Dergisi, 17(3), 497-515.

Ayyıldız Durhan, T., \& Karaküçük, S. (2017). Examination of Recreation Benefit of Parents Participating in Baby Gym Activities with Their Children. Gaziantep Üniversitesi Spor Bilimleri Dergisi, 2(4), 43-53.

Bammel, G., \& Burrus, L. L. B. (1996). Leisure and human behavior. Dubuque, IA: Wm. C. Brown Publisher.

Beşikçi, T., Irkın, F., \& Güzel, P. (2019). The relationship between leisure motivation and leisure satisfaction: A research on individuals interested in combat sports. II. World Congress of Sport Sciences Researches March 21-24, 2019, Manisa/Turkey Full Text Book.

Bilge H., \& Bal, V. (2012). Entrepreneurship aptitude: An empirical study on undergraduate and vocational high school students in Celal Bayar University. Journal of Süleyman Demirel University Institute of Social Sciences, 2(16), 131-148.

Bright, A. D. (2000). The role of social marketing in leisure and recreation management. Journal of Leisure Research, 32(1), 12-18. https://doi.org/10.1080/00222216.2000.11949878

Bülbül, A., Ölçücü, B., \& Akyol, G. (2021). The relationship between the recreational benefit awareness of sports personnel and their body liking levels. Karadeniz Uluslararası Bilimsel Dergi, 1(50), 110-123. https://doi.org/10.17498/kdeniz.934526

Çakır, V. O. (2017). The relationship between university students' leisure satisfaction levels and leisure management. Gaziantep Üniversitesi Spor Bilimleri Dergisi, 2(3), 17-27.

Carree, M. A., \& Thurik, A. R. (2003). The Impact of Entrepreneurship on Economic Growth. In Z. J. Acs \& D. B. Audretsch (Eds.), Handbook of Entrepreneurship. International 
Handbook Series on Entrepreneurship (Vol. 5). Springer, New York, NY. https://doi.org/ 10.1007/978-1-4419-1191-9_20

Çelik, A., İnce, M., \& Bozyiğit, S. (2014). A study to determine family elements affecting entrepreneurship intention of college students. Niğde Üniversitesi İktisadi ve İdari Bilimler Fakültesi Dergisi, 7(3), 113-124.

Çelikkaleli, Ö., \& Akbay, S. E. (2013). The investigation of university students' academic procrastination, general self-efficacy belief and responsibility. Ahi Evran Üniversitesi Kırşehir Eğitim Fakültesi Dergisi, 14(2), 237-24.

Çetin, A. (2019). Examining the relationship between leisure benefit and leisure satisfaction. In A. Öztürk, E. Karaçar, \& O. Y1lmaz (Eds.), Sports and Recreation Research Book-2 (pp. 53-71).

Çetinkaya Bozkurt, Ö., Kalkan, A., Koyuncu, O., \& Alparslan, A. M. (2012). The development of entrepreneurship in turkey: A qualitative research on. Journal of Süleyman Demirel University Institute of Social Sciences, 15, 229-247.

Chen, C., Cheng, C., \& Lin, S. (2013). The relationship among leisure involvement, leisure benefits, and happiness of elementary schoolteachers in Tainan county. International Research in Education, 1(1), 29-51. https://doi.org/10.5296/ire.v1i1.3970

Chen, Y. C., Li, R. H., \& Chen, S. H. (2013). Relationships among adolescents' leisure motivation, leisure involvement, and leisure satisfaction: A structural equation model. Social Indicatiors Research, 110(3), 1187-1199. https://doi.org/10.1007/s11205-011-9979-2

Chen, Y.-F., \& Lai, M.-C. (2010). Factors influencing the entrepreneurial attitude of Taiwanese tertiary-level business students. Social Behavior and Personality. An International Journal, 38(1), 1-12. https://doi.org/10.2224/sbp.2010.38.1.1

Chin-Tsai, K. (2013). Leisure involvement, leisure benefits, quality of life, and job satisfaction. International Review of Management and Business Research, 2(2), 421-428.

Çolakoğlu, H., \& Çolakoğlu, T. (2016). A field study about interaction of entrepreneurship education, self-efficacy perception, entrepreneurship potential in universities. Journal of Social Sciences and Humanities Researches, 17(17), 70-84.

Creswell, J. W. (2017). Research Design Qualitative, Quantitative, and Mixed Methods Approaches. Eğiten Book.

Damar, A. (2015). The impact of entrepreneurship personality characteristics on entrepreneurhip tendency of students: A comparative study at Sannio and Selcuk universities (Master Thesis, Selçuk University Institute of Social Sciences Management Department Management Organization Department).

Demir, A. Z., Eliöz, M., Çebi, M., \& Sezen, S. (2015). Entrepreneurship and entrepreneurial university: A study on the students of faculty of sports. Ondokuz Mayis University Journal of Faculty of Education, 34(1), 198-212. https://doi.org/10.7822/omuefd.34.1.12 
Dergance, J. M., Calmbach, W. L., Dhanda, R., Miles, T. P., Hazuda, H. P., \& Mouton, C. P. (2003). Barriers to and benefits of leisure time physical activity in the elderly: Differences across cultures. Journal of the American Geriatrics Society, 51(6), 863-868. https://doi.org/ 10.1046/j.1365-2389.2003.51271.x

Doğaner, M., \& Altunoğlu, A. E. (2010). Adnan menderes university, nazilli economic and administrative sciences fakulty, business administration department students' entrepreneurship tendency. Organizasyon ve Yönetim Bilimleri Dergisi, 2(2), 103-110.

Edginton, R. C. (2006). World Leisure: Enhancing Quality of Life. International Journal of Applied Sports Sciences, 18(2), 108-120.

Erdemli, E. (2019). Examining the relationship between the attitude of physical education and sports teachers towards the profession and the levels of free time satisfaction (Master Thesis, Bartın University Institute of Educational Sciences Department of Physical Education and Sports Teaching Program Physical Education and Sports Training).

Erdemli, E., \& Yaşartürk, F. (2020). Examination of the relationship between free time satisfaction level and problem solving skills of physical education and sports teaching department students. MANAS Journal of Social Studies, 9(3), 1871-1882.

Ertekin, A. B. (2020). Relationship between entrepreneurship levels and career awareness of students studying in the field of sports education. Inonu University, Journal of Physical Education and Sport Sciences, 7(3), 14-27.

Ertekin, A. B. (2021). The Relationship between Innovation Skill and Entrepreneurship on Bachelor Students of Sports Education. Journal of Educational Issues, 7(1), 326-336. https://doi.org/10.5296/jei.v7i1.18405

Ertüzün, E., Hadi, G., \& Fidan, E. (2020). Examining sports center members' leisure benefits with regard to some variables. Journal of Sports and Performance Researches, 11(3), 221-230.

Filiz, B., \& Doğar, Y. (2021). The effect of academic procrastination tendencies of physical education teacher candidates on self-regulation skills and self-efficacy. Milli Ĕgitim Dergisi, 50(230), 857-872.

George, D., \& Mallery, M. (2010). SPSS for windows step by step: A simple guide and reference (17.0 Update, 10th ed.). Boston: Pearson.

Gökalp, M., \& Soykan, F. (2020). Academic hopelessness scale: Development, validity and reliability study. MANAS Journal of Social Studies, 9(2), 741-751. https://doi.org/10.33206/ mjss.562714

Gökçe, H. (2015). Effect of rekreational activities on students' studying for University entrance exam self-efficacy, test anxiety, and leisure satisfaction level (Ph.D Thesis, Ankara University Institute of Health Sciences, Department of Sport Sciences).

Güçlü, M. (2013). The significance and importance of leisure time activities in youth period. 
Gençlik Araştırmaları Dergisi, 1(1), 158-169.

Güldür, B. B., \& Yaşartürk, F. (2020). Examination of relation between life satisfaction level and benefits of participation to leisure activities of pre-school teachers. International Journal of Contemporary Educational Studies, 6(2), 495-506.

Heintzman, P. (2009). The spiritual benefits of leisure. Leisure/Loisir, 33(1), 419-445. https://doi.org/10.1080/14927713.2009.9651445

Ho, T. K. (2008). A study of leisure attitudes and benefits for senior high school students at Pingtung city and country in Taiwan (Unpublished doctoral dissertation, United States Sports Academy, Daphne, AL).

Hsieh, S., Spaulding, A., \& Riney, M. (2004). A qualitative look at leisure benefits for Taiwanese nursing students. The Qualitative Report, 9(4), 604-629. https://doi.org/10.46743/ $2160-3715 / 2004.1906$

Huang, C., Tsai, C., \& Lee, S. (2014). A study of the influence of college students' exercise and leisure motivations on the leisure benefits-using leisure involvement as a moderator. World Academy of Science, Engineering and Technology International Journal of Humanities and Social Sciences, 8(8), 2427-2431.

Huang, Y. (2013). A study on the relationships between leisure activity involvement, well-being, the benefits of serious leisure activity, and sports volunteer self-actualization in the changhua national games. The Journal of Human Resource and Adult Learning, 9(1), $12-25$.

Hung, H. J. (2012). A study on leisure benefits breaking through leisure activities. Journal of National Taiwan Normal University, 3(4), 77-92.

İlhan, S. (2005). The entrepreneur profile in elazı $\breve{g}$ in terms of some variables. Firat Üniversitesi Sosyal Bilimler Dergisi, 15(1), 217-248.

İşmar, Z., \& Şehitoğlu, G. (2021). A research on the relationship between academic self perception and academic success. Uluslararası Anadolu Sosyal Bilimler Dergisi, 5(1), 78-99.

Iwasaki, Y. (2006). Leisure and quality of life in an international and multicultural context: What are major pathways linking leisure to quality of life? Social Indicators Research, 82, 233-264. https://doi.org/10.1007/s11205-006-9032-z

Karaküçük, S., Ayyıldız Durhan, T., Akgül, B. M., Aksın, K., \& Özdemir, A. S. (2019). The relationship between recreation benefit and ecocentric, anthroposentric, antipatic approaches in orienteering athletes. Gazi Üniversitesi Gazi Eğitim Fakültesi Dergisi, 39(3), 1263-1288

Karaman, G. (2020). Relationship of stress and anxiety with academic success of university students (Master Thesis, Istanbul Gelisim University Graduate Education Institute, Department of Psychology, Department of Clinical Psychology).

Karataş, İ. (2018). Examining the effects on entrepreneurship trends of the personality traits of the students of the school of physical education and sports: The case of Bartin University 
(Master Thesis, Bartın University Institute of Educational Sciences Department of Physical Education and Sports Teaching Department of Physical Education and Sports Teaching).

Karıman, E. (2017). A study on the students of Ondokuz Mayis University on the path to become an entrepreneurial University (Master Thesis, Ondokuz Mayıs University, Institute of Health Sciences, Department of Physical Education and Sports).

Keleş, H., Kıral Özkan, T., Doğaner, M., \& Altunoğlu, A. (2015). A research on determining the levels of entrepreneurship of students with an associate's degree. International Journal of Economic and Administrative Studies, 9.

Kocaer, G. (2018). The investigation of the relationship between physical education and sports teachers 'and candidates' attitudes towards teaching profession, free time interests and benefit levels for recreation activities (Bartın province case) (Master Thesis, Bartın University Graduate School of Educational Sciences Department of Physical Education and Sports Teaching).

Koh, H. C. (1996). Testing hypotheses of entrepreneurial characteristics a study of hong kong mba students. Journal of Managerial Psychology, 11(3), 12-25. https://doi.org/10.1108/02683 949610113566

Korkmaz, O. (2012). A research on determining the entrepreneurialism inclination of university students: Bülent Ecevit University example. Afyon Kocatepe Üniversitesi IIIBF Dergisi, XIV(II), 209-226.

Landström, H. (2005). Pioneers in entrepreneurship and small business research. Springer Science. https://doi.org/10.1007/b102095

Lee, C. J., Tseng, C. C., \& Liu, M. Y. (2015). Study on community Tai Chi Chuan participants' leisure benefits and well-being: Using Taoyuan City as an example. Technology and health care: Official journal of the European Society for Engineering and Medicine, 24(Suppl. 1), 289-295. https://doi.org/10.3233/THC-151086

Liñán, F., Moriano J. A., \& Zarnowska A. (2008). In J. A. Moriano, L. M. Gorgievski \& M. Lukes (Eds.), Stimulating entrepreneurial intentions through education, teaching psychology of entrepreneurship perspective from six european countries (pp. 45-67). Universidad Nacional de Educación a Distancia, Madrid.

Munusturlar, S. (2016). Leisure and recreation concept. In M. Aky1ldı Munusturlar (Ed.), Recreation Management (pp. 2-26). Anadolu University Press, Turkey.

Özman, C. (2013). Assessment of the entrepreneurship level of the university students at the sports management departments (Master Thesis, Marmara University Institute of Health Sciences Department of Physical Education and Sports).

Özmen, Ç. (2015). An evaluation of entrepreneurship level of fourth grade students in recreation and sports management department (Master Thesis, Mehmet Akif Ersoy University, Institute of Educational Sciences, Department of Physical Education and Sports Teaching). 
Öztürk, M. (2018). Examining the relationship between entrepreneurship characteristics and reflective thinking levels of pre-service teachers (Master Thesis, Bartın University Physical Education Department Curriculum and Instruction).

Pan, V., \& Akay, C. (2015). Examining teacher candidates' entrepreneurship levels in terms of various variables. Education Sciences, 10(2), 125-138.

Philipp, S. F. (1997). Race, gender, and leisure benefits, leisure sciences. An Interdisciplinary Journal, 19(3), 191-207. https://doi.org/10.1080/01490409709512249

Pihie, L., \& Akmaliah, Z. (2009). Entrepreneurship as a career choice: An analysis of entrepreneurial self-efficacy and intention of university students. European Journal of Social Sciences, 9(2), 338-349.

Polat, E. (2017). Academic achievement and its relationship with anxiety level and academic self-efficacy. Journal of Management and Economies Research, 15(1), 1-22. https://doi.org/ 10.11611/yead.312024

Rençber, B. A. (2012). Factors which affect academic achievement of university students. Çankırı Karatekin Üniversitesi Sosyal Bilimler Enstitüsü Dergisi, 3(1), 191-198.

Şeras, H. (2017). Examining satisfaction and perceived freedom level of employes of ministry of food agriculture and livestock in leisure activities they attend (Master Thesis, Bartın University Instutite of Educational Sciences, Physical Education and Sports Teaching Department Physical Education and Sports Teaching Department).

Serdar, E. (2020). Relationship among leisure attitudes, leisure satisfaction and perceived health outcomes in recreation (Ph.D Thesis, Istanbul University-Cerrahpaşa Graduate School of Education, Department of Sport Management Sciences).

Serdar, E. (2020). The relationship between leisure benefit and happiness: Students of the faculty of sports science. Turkish Studies-Social, 15(5), 2711-2721. https://doi.org/10.47356/ TurkishStudies.44273

Serdar, E., \& Demirel, M. (2020). The relationship between perceived stress and leisure satisfaction: Example of sports sciences students. Atatürk Üniversitesi Beden Ë̆itimi ve Spor Bilimleri Dergisi, 22(3).

Serdar, E., Demirel, M., Harmandar Demirel, D., \& Donuk, B. (2018). The relationship between the level of leisure satisfaction and the level of happiness of university students. The Journal of Social Sciences, 5(28), 429-438. https://doi.org/10.16990/SOBIDER.4412

Şeşen, H., \& Basım, H. N. (2012). The impact of demographic factors and personality on the entrepreneurial intention: A study on students in sport sciences departments. Ege Academic Review, 12, 21-28.

Shariff, M. N. M., \& Saud, M. B. (2009). An attitude approach to the prediction of entrepreneurship on students at institution of higher learning in Malaysia. International Journal of Business and Management, 4(4), 129-135. https://doi.org/10.5539/ijbm.v4n4p129 


\section{Macrothink}

Shyu, C. S. (2012). A study on the relationship among free-time management, leisure constraints and leisure benefits of employees in resort hotel. The Journal of Global Business Management, 8(1), 166-174.

Siyahtaş, A. (2020). Investigation of loneliness and satisfaction levels of individuals participating in leisure activities (Master Thesis, Istanbul University-Cerrahpaşa Graduate School of Education, Department of Sport Management Sciences).

Tays1, K., \& Canbaz, S. (2014). A research on identifying enterpreneurship qualities and tendencies of the students of associate degree. Electronik Journal of Vocational Colleges, 4(1), 59-57.

Tekin, A., Tekin, G., \& Çalışır, M. (2017). Recreational Sport. In S. Karaküçük, S. Kaya, \& B. M. Akgül (Ed.), Sciences of Recreation 2 (pp. 3-37).

Tezcan, M. (1993). Leisure sociology. Ankara University Faculty of Educational Sciences Publications.

Thandi, H., \& Sharma, R. (2003) MBA students and entrepreneurship: An Australian study of entrepreneurial intentions and actualization. Jirsea, 2(1), 2-24.

Üstün, Ü. D., \& Aktaş Üstün, N. (2020). Investigation of university students' realization of the benefits of leisure activities. Sportif Bakış: Spor ve Ĕgitim Bilimleri Dergisi, 7(SI1), $38-48$.

Yan, W. (2013). Correlations of consumers, leisure motivation and leisure value with leisure benefits-A case study on Taiwan international orchid show. International Journal of Academic Research in Business and Social Sciences, 3(3), 267-276.

Y1ldı, E. (2020). Investigation of entrepreneurship levels of inönü university faculty of sport sciences students (Master Thesis, İnönü University Institute of Health Sciences Department of Physical Education and Sports).

Yıldız, M., Kırtepe, A., \& Baydili, K. (2021). Examining the relationship between academic achievements and time management skills of the students at the faculty of sports sciences. Atatürk Üniversitesi Beden Eğitimi ve Spor Bilimleri Dergisi, 23(1), 55-70.

Y1lmaz, E., \& Sünbül, A. M. (2009). Developing Scale of University Students Entrepreneurship. Selçuk Üniversitesi Sosyal Bilimler Enstitüsü Dergisi, 21, 196-203.

Yüceol, N. (2018). A research on the relationship between entrepreneurial personality traits and entrepreneurial tendency of individuals with entrepreneurship education (Master Thesis, Istanbul Gelisim University, Institute of Social Sciences, Department of Business Administration).

Yüksel, H., Cevher, E., \& Yüksel, M. (2015). A research on the inclinations of entrepreneurship and entrepreneurship personality characteristics of students. Çankırı Karatekin Üniversitesi IIIBF Dergisi, 5(1), 143-156. 


\section{Macrothink}

Journal of Educational Issues

ISSN 2377-2263

2021, Vol. 7, No. 2

Zajacova, A., Lynch, S., \& Espenshadet, T. (2005). Self-efficacy, stress, and academic success in college. Research in Higher Education, 46(6), 677-706. https://doi.org/10.1007/ s11162-004-4139-z

\section{Copyright Disclaimer}

Copyright for this article is retained by the author(s), with first publication rights granted to the journal.

This is an open-access article distributed under the terms and conditions of the Creative Commons Attribution license (http://creativecommons.org/licenses/by/3.0/). 